FACTA UNIVERSITATIS

Series: Linguistics and Literature Vol. 18, No 1, 2020, pp. 53-61

https://doi.org/10.22190/FULL2001053K

Original Scientific Paper

\title{
NUANCE OF ANIMISM IN THE PROSE OF ŽIVKO ČINGO
}

\author{
UDC 821.163.3.09-32 Čingo Ž.
}

\section{Danijela D. Kostadinović}

University of Niš, Faculty of Philosophy, Serbian Department, Niš, Serbia

\begin{abstract}
Starting from the theoretical settings of folklore study, history of religion anthropology and psychoanalysis, this paper studies the elements of animistic beliefs in the prose of the Macedonian writer Živko Čingo. The research material consists of the short stories “Духови в куки”, “Вљубениот дух”, “Лудите роднини во борба со прекобното пиле" and "Пеперуга со златна прав". The aim of this paper is to confirm that these stories establish a link with animism and the belief in the existence of soul in all animate and inanimate entities and phenomena in nature, and the belief that the soul continues to live after death.
\end{abstract}

Key words: Macedonian literature, Živko Čingo, animism, spirit, soul, life

\section{INTRODUCTION}

Animism (from the Latin word anima meaning BREATH, SOUL, LIFE), in a broader sense, entails the belief that spirits can reside in animate and inanimate entities and phenomena. Pejović (1989: 27) describes it as faith in independent mental or spiritual beings outside or above everything bodily, which act on or govern our lives, namely the initial stage of every religion, i.e. the main feature of primitive mentality. Animism, in Pejović's opinion, should be distinguished from animatism, which refutes the thesis that animism is the initial religious stage. He advocates the theory that the original religion was based on faith in something supersensible, a powerful belief in some spiritual other which permeates everything bodily and is found in everything that surrounds man.

The animistic theory was established by Edward B. Tylor, an evolutionist, historian of religion and anthropologist, in his study Primitive Culture (1871). Tylor (1871) defines animism as the first stage of evolutionary religious development. He proposes the hypothesis that the primitive man believed in the existence of a sensual, visible, extrasensory, and invisible world that one enters in a dream. The primitive man believed

Submitted June 10, 2020; Accepted June 23 , 2020

Corresponding author: Danijela Kostadinović

University of Niš, Faculty of Philosophy

E-mail: danijela.kostadinovic@filfak.ni.ac.rs 
that the soul continues to live after death, and that both animals and plants possess a soul. The souls of the dead can visit the living and determine their destiny, which leads further to the idea of immortality and the development of a cult of the dead. Tylor (1871: 260) states the following:

"Animism takes in several doctrines which so forcibly conduce to personification, that savages and barbarians, apparently without an effort, can give consistent individual life to phenomena that our utmost stretch of fancy only avails to personify in conscious metaphor. An idea of pervading life and will in nature far outside modern limits, a belief in personal souls animating even what we call inanimate bodies, a theory of transmigration of souls as well in life as after death, a sense of crowds of spiritual beings, sometimes flitting to the air, but sometimes also inhabiting trees and rocks and waterfalls, and so lending their personality to such material objects..."

Subsequent scientific discussions related to the theory of animism and especially to the theory of the so-called common ancestors of mankind, discussed their, not so naive colonialist background. This would first lead to a partial rejection of the term animism, and then to its revision within various scientific disciplines: philosophy, ethnology, child psychology, studies in folklore (cf. Harvey 2005).

Animistic beliefs are, therefore, present in all nations of the world, and according to most theorists, they appear at the earliest stage of religious development. Among the Slavs, they are also widespread and originate from the distant pagan past. The encyclopedic dictionary Словенска митологија states that Slavic paganism carried in itself not only animatistic beliefs (the belief that everything in nature is alive $\rightarrow$ stone, fire, wood, thunder), but also animistic beliefs (i.e. notions of the soul), which were probably related to later needs concerning the transcendence of the soul (i.e. its ability to pass to another body) and the ability of various metamorphoses of supernatural beings which transform into a goat, a dog, a cat, a child, etc. After the conversion of the Slavs to Christianity, supernatural beings, being given the name unclean force, had a human, anthropomorphic, animal - zoomorphic or mixed anthropomorphic-zoomorphic form. This force, according to the belief of the old Slavs - pagans, inhabited the entire universe, they encountered it, and it was dangerous, although it did not always lead to a bad and tragic end. This force could be propitiated and even scared away, which was done in accordance with special rituals and traditions. It seems that the Slavs in the VI century had not only something like a pantheon of Gods or local "tribal" pantheons, but they were close to monotheism, the belief in the supreme, but not yet a single one, Christian God.

The famous Serbian historian of religion Čajkanović (1994: 71-74), in his writings about the soul, points out that, according to folk beliefs, the soul can be either organic, i.e. dynamic, tied to one part of the body, or to the whole body, or something different from the body, and it can be, temporarily or once and for all, separated. In the latter case, the soul is free, and has the character of a separate person; the soul is, for the most part, man's 'spiritual' duplicate, his alter ego, his psyche [...] Our people, starting from various understandings, sometimes refer to that soul by the name (word) of the $d u \check{s} a$ (in its narrowest meaning); on other occasions they call the soul by the name sen (shadow). The word $d u \check{s} a$ (which is, both in its form and meaning, common Slavic word and therefore both the word and the term are very old) is etymologically related to blowing [...] therefore, it originally represents human breath, i.e. the last breath, with which all life functions are extinguished (Čajkanović 1994: 71-74).

The meaning of the soul as a spiritual duplicate is also found in Jung's reflections on the archetypes of anima and animus. From Jung's point of view, anima is an archetype of the 
female and female label in the male psyche, which can have both positive and negative connotations ("The anima is a personification of all feminine psychological tendencies in a man' s psyche, such as vague feelings and moods, prophetic hunches, receptiveness to the irrational, capacity for personal love, feeling for nature , and - last but not least - his relation to the unconscious" (Jung 1988: 176), and vice versa, animus represents the male component of the female psyche ("The male personification of the unconscious in woman - the animus exhibits both good and bad aspects, as does the anima in man. But the animus does not so often appear in the form of an erotic fantasy or mood; it is more apt to take the form of a hidden 'sacred conviction" (Ibid: 189)). Both anima and animus are sometimes demons of death. In fact, Jung (1971: 243) points out that the concept of the soul is subject to multiple interpretations, that the soul is at the same time connected with the maternal aspect of the earth and the sublime aspect of the sky, and that it signifies the personification of unconscious contents:

"Looked at historically, the soul, that many-faceted and much interpreted concept, refers to a psychological content that must possess a certain measure of autonomy within the limits of consciousness. If this were not so, man would never have hit on the idea of attributing an independent existence to the soul, as though it were some objectively perceptible thing. It must be a content in which spontaneity is inherent, and hence also partial unconsciousness, as with every autonomous complex “[...] ,As against this historical evolution of the idea of the soul, analytical psychology opposes the view that the soul does not coincide with the totality of the psychic functions. We define the soul on the one hand as the relation to the unconscious, and on the other as a personification of unconscious contents. From the civilized standpoint it may seem deplorable that personifications of unconscious contents still exist, just as a man with a differentiated consciousness might well lament the existence of contents which are still unconscious. But since analytical psychology is concerned with man as he is and not with man as he would like to be, we have to admit that those same phenomena which impel the primitive to speak of "souls" still go on happening, just as there are still countless people among civilized nations who believe in ghosts."

In the context of the theory of animism, the thinking of Émile Durkheim is also important, as presented in the book Elementary Forms of Religious Life. Namely, Durkheim writes about the existence of two closely connected and permeated religions, which, however, differ from each other. These are naturalism and animism. The former addresses things of nature such as great cosmic forces such as winds, rivers, stars, the sky, or it addresses various objects on earth, plants, animals, rocks, while the object of the latter are the spiritual beings as its object, spirits, souls, geniuses, demons, divinities properly socalled, animated and conscious agents like man, but distinguished from him, nevertheless, by the nature of their powers and especially by the peculiar characteristic that they do not affect the senses in the same way: ordinarily they are not visible to human eyes (Durkheim 2012, 49). Animism pays special attention to the cult of spirit and soul, and these concepts, according to Durkheim, cannot be equated. The dream experience suggested the idea of the soul, which could be reduced to the idea of a double. Accordingly, Durkheim (Ibid: 52) points to the connection of the soul and the body, especially in the state of sleep, when the soul leaves the body for a certain period and returns to it at the time of awakening, while the spirit is connected exclusively with the moment of impending death:

"Thus it seems that it too consists in a separation of the soul and the body, analogous to that produced every night; but as in such cases, the body is not reanimated, the idea is 
formed of a separation without an assignable limit of time. When the body is once destroyed - and funeral rites have the object of hastening this destruction - the separation is taken as final. Hence come spirits detached from any organism and left free in space. As their number augments with time, a population of souls forms around the living population. These souls of men have the needs and passions of men; they seek to concern themselves with the life of their companions of yesterday, either to aid them or to injure them, according to the sentiments which they have kept towards them. According to the circumstances, their nature makes them either very precious auxiliaries or very redoubtable adversaries. Owing to their extreme fluidity, they can even enter into the body, and cause all sorts of disorders there, or else increase its vitality. Thus comes the habit of attributing to them all those events of life which vary slightly from the ordinary: there are very few of these for which they cannot account. Thus they constitute a sort of ever-ready supply of causes which never leaves one at a loss when in search of explanations. Does a man appear inspired, does he speak with energy, is it as though he were lifted outside himself and above the ordinary level of men? It is because a good spirit is in him and animates him. Is he overtaken by an attack or seized by madness? It is because an evil spirit has entered into him and brought him all this trouble. There are no maladies which cannot be assigned to some influence of this sort. Thus the power of souls is increased by all that men attribute to them, and in the end men find themselves the prisoners of this imaginary world of which they are, however, the authors and the models. They fall into dependence upon these spiritual forces which they have created with their own hands and in their own image. For if souls are the givers of health and sickness, of goods and evils to this extent, it is wise to conciliate their favor or appease them when they are irritated; hence come the offerings, prayers, sacrifices, in a word, all the apparatus of religious observances"

\section{ANIMISM IN ČINGO’S STORIES}

Within the stated theoretical reflections on animism, we will discuss the stories “Духови в куќи”, “Вљубениот дух”, “Лудите роднини во борба со прекобното пиле” and "Пеперуга со златна прав" by the contemporary Macedonian writer Živko Čingo. Essentially, the stories are based on the popular belief that the human soul can reside in objects, animals and plants, that the deceased's spirit can wander in the gap between mundane and spiritual reality and that the souls live forever.

With a narrative process based on folklore patterns, mythical-magical and archetypal images and plays, Živko Čingo depicts the period after the Second World War in Macedonia, marked by the differentiation of two dialectics which try to control each other: communist utopias and Pagan-Christian mystics. Although the new communist world seeks to destroy the old traditional religious system violently, it hovers over it like a shadow, penetrating all its pores, since archetypes have a strong energy potential of the past and memory and take place on an impulsive and instinctive, collectively unconscious level. As Jung believed (1990, 224), archetypes are typical forms of understanding, and wherever there are uniform and correctly repeated understandings, it is an archetype, regardless of whether its mythological character is known or not." The collective unconscious consists of the sum of instincts and their correlates, archetypes. As every man possesses instincts, so he possesses primordial images.

The stories of Živko Čingo, the subject of our analysis, establish a strong connection with the animistic beliefs of the Macedonian folklore, which is confirmed by the fact that 
the nouns $\partial y x$ and $\partial y m a$ are repeated many times, and the noun spirit even in the titles: "Spirits in the house" and "A spirit in love". Everything animate and inanimate in these tales has a soul, and spirits can be good and evil, come from the other world, and inhabit animals and other beings. The primitive soul, Dil $(1991,21)$ observes, projects its own intentionality (human motives) not only onto the transcendent image of the deity but also into everything that exists in reality: onto animals, plants, and even inanimate objects as objects of desires and fears. It seems to us that the entire nature is inspired by good or bad intentions towards us, depending on our merits or sins.

With a slight irony, in "Духови в куќи” С̆ingo writes the short story that spirits, despite the empirical logic of the twentieth century, exist:

“Сите говореа немат веќе духови, дваесетти век, а ете нив да ги имало. Скриени живееле во разни предмети, во дрвјата, во водите, а некои во животните.” (Čingo 1992: 373).

The main source of this story is in the folk belief in the existence of evil spirits, which can occur in various beings, objects and phenomena in nature. In this story, the evil spirit has moved into a dog that howls for weeks, and thus not only invokes and foretells evil and misfortune, but they also reside in himself.

In many mythologies, the dog is identified with the underworld and hell. In Serbian and Macedonian folk beliefs, the dog is also given the power of divination, that is, by his howling he senses the death in the house. The dog is the guardian of the border of social and wild space from the center of the social, where the human house is located, to the border of the wild space (Radenković 1996, 99). The border feature of the dog precisely gives the understanding that the dog can announce illness or death (Ibid), which is also the case in Čingo's short story “Духови в куќки”.

The conflict situation in the story arises from confronting two different beliefs. Namely, on the one hand, the dog is given predictive meanings and meanings of a chthonic mythical character, an evil spirit and demon, a messenger of death, a psychopomp who must be destroyed in order for life to continue. On the other hand, there are totemic beliefs that a brotherhood or tribe can be related to an animal, in this case to a dog, and that the animal is a taboo and must not be killed, because that would harm the whole fraternity, i.e. the tribe.

The story of spirits introduces the reader to an inner, immanent narrative, motivated by the arrival of an unknown man on a horse from a "distant, desolate road" to the protagonist's family home, who is a boy who lives in fear and dread because the youngest member of the family lies on his deathbed. In accordance with the folk customs of the special status of the guest and the indication of hospitality, the boy's father allows the stranger to spend the night in the house. The description and metamorphosis of a stranger at the moment when he hears the howling of a dog near the well, determine his mythical and status of a representative of another world, already hinted by the status of a guest and the space from which he comes:

"Мал, неубав, слабо, грдо човече, со црни болчиња на лицето, лицето му беше како грбот на крастава жаба, но како мавташе со рачињата, како тупотеше со ножињата, како испушташе некои гласови,-некако почнуваше да се престорува во друг. Како да не беше тој, туку некој друг, поголем, поубав од него, силен, не некој со краста на лицето, туку со добри очи, светли. Едно време толку много ме занесе што моравме да помислиме, - сигурно тој беше некој старински човек, божем, во старо време малите луѓе биле големи, слабите најсилни, секако се престорувале,-навистина така 
било во старо време,- сосема ја оставивме играта и се загледавме о него сиромашкиот,-како деца проклето кога ќе се загледаат во нешто. Но тој веќе не гледаше во нас, еден момент вресна како јаре, викна: - „Пријателе! Еј пријателе!“ викаше по татко ми сѐ така мавтајќи со малите рачиња час удирајќи по себе, час замавнувајќи во воздухот, со нешто како да се бореше, при секое негово замавнување од лево од десно ќе чуевме пискотница, навистина. После се јави духот." (С̌ingo 1992, 376)

Judging by the status given to the stranger, he was expected to take the initiative and order the father to kill the dog, which howls ominously in order to save the life of a sick child. The hesitation of the head of the family to kill a dog should be interpreted in the context of taboos, as it was pointed out above; he will do that only at the urging of his wife and the mother of the sick child. This gives preference to the feminine and maternal principle in the structure of the family community.

On the other hand, the place next to the well was not chosen by chance, since the well is at the same time the border between the two worlds, the entrance to the underworld and to the other side (cf. Kulišić, Petrović, Pantelić 1970, 57; Tolstoj Radenković 2001, 58), while water is the element especially attractive for the soul [...] It has the power of attraction because in the underworld, according to the general understandings of both Semitic and Indo-European people, there is eternal thirst (Čajkanović: 82).

The short story "Вљубениот дух", which is a true poetic miniature, is one of Čingo's most successful narrative achievements. Prosopopoeia is the basis of its stylistic formation, permeated with the belief that death does not mean the ending and that great desire and strong love can summon the spirit of the deceased:

“Ѝ зборуваше на покојната, со неа разговараше, како да е жива, како да се сами, како да се во својата куќа, заедно со своето детенеце [...] Но тој ништо живо не го делеше од гробот, никого не слушаше, тој ја бараше неа, својата жена, ја колнеше во рожбата да му се врати, зашто дома, рече, ми те чека нашето сунце, нашето дете, тоа само тебе ми те бара, ништо не го смирува [...] Човекот умира, ама духот живее, духот не се закопува, има едни такви души кои остануваат вечно, не се губат...” (С̌ingo 1992, 403, 404).

The thematic basis is the story of the teacher Cvetan Cvetanoski, who after the death of his beloved wife Ana became estranged from the world and in a remote village shortened his hours of loneliness by writing his own thoughts about life in a diary. In this story, as noted by (Georgievski 1985, 121), Čingo applies a more complex procedure while building the hero's irrationality. By introducing the diary text, the author-witness separates the hero from external events towards the unconscious, towards the obsessive motive, thus deepening his tragedy. (Georgievski 1985, 121)

The figure of the prosopopoeia and the diary are, therefore, the main bearers of the narrative flow, motivated by the arrival of hunters in the mountain village of Zovič and meeting the teacher Cvetan Cvetanoski and the school servant Jančulo. In the middle of horrible winter devastation of a mountain village, the teacher tells the story of a young woman from Zovič Ana who died after giving birth, whose husband could not get over it, and every day, as someone called him, he went to the grave and returned from the cemetery happier, pronouncing aloud and writing down in a notebook always the same verse: “Зимско цвеќе, зимско цвеќе некој ти фрлил во гробот, љубов!” (Čingo 1992, 399). Having in mind the words of Radenković $(1996,40)$ that the other world is seen as the space of eternal silence, one of the fences towards it is the 'sound' wall, the verses 
that the protagonist utters aloud obsessively in a certain form represent a defense mechanism and non-acceptance of reality, with which the compulsive action of going to the cemetery is deeply connected. In such a symbolic frame is given the ringing of window panes, which precedes the appearance of a beautiful woman at the window:

“Тоа беше на годината од смртта на жената, истото време, пролетно, грееше силно сонце на небото, а и врнеше, се топеше снегот, капајците како молзници течеа. Едно време во ушиве ми заsвонија стакленцата на прозорчето, не обратив много внимание првиот пат, не обратив поголемо внимание, оти на клинчина се држеа стаклата, без туткал, па нормално што заsвони. Бележев нешто, што се вели, бев под инспирација, а тоа sвони, sуни! Просто ме повикува, гледам на стакленцето прекрасен женски лик, непозната ми се смее, ми зборува нешто,... Мислам ми се причинува, виножито, сонцето и дождот се помешале, дури си ги протрив и очиве, нели... А таа се смее, сонце грее, чудесен призрак косата цела во срма, на главата венче, бело променета, невеста... О боже, занемев!” (С̌ingo 1992, 406)

The peculiarity of the other world, its laws, limited knowledge, but also the mysterious and close connections between the earthly and the otherworldly are reflected in the final segment of the story when the apparition disappears the moment the teacher approaches the window, opens it, and then disappears into the night as if blown away by the wind.

The story "Луди роднини во борба со прекобното пиле" is close to the story “Духови в куќи” and the story "Вљубениот дух". The plot of the story is constructed on the belief that the chicken has the power to predict "time, arrival of a guest, journey or death" (Kulišić, Petrović, Pantelić 1970, 243).

The protagonist of the story returns from Frankfurt to his native village to inform Venda, his sister (uncle's daughter), that her fiancé was dead. Venda lived with her grandmother Andja and they were his only relatives. The plan of realistic motivation in the framework segment gives way to the inner story, stylized in the form of a dream, before the magical reality - the boundaries between dream and reality, life and death are completely erased. The real moment is crossed with the irrational. In the attic, Venda virtuously plays some strange instrument while grandmother Andja listens to her carefully and praises her playing. The astonishment is realized by their inability to see the physical presence of the main character in the yard and the family house. In the main character this strangeness will evoke the memory of the war in which his father was killed and the moment when an ominous chicken appeared and the grandmother started fighting him. Transferred to a symbolic level, this conflict meant a battle with an unclean force for the life of another son, who also took part in the war:

“Од тој момент почна таа ужасна борба меѓу баба и тоа пиле, ни секунда не губеше баба. Како ветар влезе во куќата, најде некое тенеке за жито, го зеде тоа и со него како некоја чергарка тропајќи, викајќи појде низ нашата градина. Одеше од дрво до дрво, удираше сѐ посилно и посилно, а глас како да имаше за илјада луѓе, и сигурно сите тоа го слушаа во долината, и поблиску и подалеку ечеше.” (С̌ingo 1992, 441)

After the news arrived that Venda's father had returned from the war, the chicken disappeared in order to reappear in the real time frame of the final part of the story, shaped by elements of oneiric fiction. Hero is woken up from the dream by the familiar voice of an ominous chicken and the wondrous music coming from the yard. Down, in the yard, some unknown children were choosing the instruments. Venda, dressed in a white wedding dress, beautiful as a fairy, walks slowly holding a miraculous instrument in 
her hands. Behind her, together with other children, runs the grandmother masterfully performing a song on some, strange instrument. The whole valley is filled with that strange music never heard before. It could be concluded that this is, in fact, a ritual of a magical nature, where the impure forces are dispersed by playing miraculous and unusual instruments. According to the Српски митолошки речник, sound is used in beliefs to scare and chase evil spirits and demons. It is produced by shouting and using rattles, drums, tree trumpets, banging on metal objects, bell, rifle shooting and pistols (cf. Kulišić, Petrović, Pantelic 1970, 146). At the end of the story, the hero himself becomes part of the magicritual, takes the instrument and joins his relatives.

In the short story "Пеперуга со златна прав", the main character, a young man Lem, is described as being the most in love out of all the boys, the most in love in the whole human race:

“Беше сосема сам. И заљубен. Ох, заљубен, слободно речете луд. Сосема изветреа братучедот Лем, беше заљубен како ѓавол.” (Čingo 1992, 308)

Considering that the main character Lem possessed the power to turn into a seed, into a spike, into a grain, and into everything that exists, the Paskvelians were convinced that there was a converted demon hiding in him, who had the ability to enchant girls and who is to be avoided to keep his distance and avoid him. What made Lem different from others and special was his talent for telling stories. He tells stories about a butterfly with gold dust on its wings, about the queen of butterflies, fairies in which all girls believe, and after those stories he is also called a butterfly with gold dust.

Between the butterfly and the soul, in this story, certain analogies have been established, which have their basis in Slavic folk beliefs, where the butterfly is often associated with representations of demons, that is, it represents a soul that can move independently of the body (Kulišić, Petrović, Pantelić 1970, 204-205), then in the belief that the soul that is leaving the body of the deceased has the shape of a butterfly, that is, he is the incarnation of the soul. (cf. Tolstoy, Radenković 2001, 335), as well as in Christian symbolism, where the butterfly symbolizes a soul deprived of its body envelope (Gerbran, Ševalije 2004, 488).

\section{CONCLUDING REMARKS}

Živko Čingo transferred different conceptions and traditional images of spirit and soul to the level of his stories as symbolic signs of an invisible reality which has a strong effect on man. Just leaving Paskvelija - the Garden of Eden, after the communists came to power, is a distant echo of the belief in the duality of the soul and symbolizes the loss of the existential essence of the Paskvelian folklore religious man. Paskvelians are transformed into shadows, into dead souls (which is in accordance with Jung's definition of shadow as a set of hidden, unsuitable properties of the psyche, insufficiently developed functions and contents of the unconscious), and Paskvelija itself into the Desert, into a world of darkness without rays of light. ${ }^{1}$

\footnotetext{
${ }^{1}$ Based on the adapted and revised version of the chapter "Animistička verovanja u prozi Živka Činga" in Kostadinović, D. (2014), Elementi magičnog realizma u prozi Slobodana Džunića i Živka Činga (Unpublished doctoral thesis), University of Belgrade, Serbia.
} 


\section{REFERENCES}

Георгиевски, Христо. 1985. Поетиката на македонскиот расказ. Скопје: Мисла.

Чинго, Живко. 1992. Пасквелија, Избрани дела, кн. 1-4, пр. Петар Т. Бошковски, Скопје: Култура.

Čajkanović, Veselin. 1994. Old Serbian religion and mythology. Belgrade: SKZ.

Diel, Paul. 1991. Symbolism in the Bible. Translated by Jelena Stakić. Sremski Karlovci / Novi Sad: Izdavačka knjižarnica Zorana Stojanovića.

Durkheim, Emile. 2012. The Elementary Forms of Religious Life. Translated from French by Joseph Ward Swain. London: George Allen\&Unwin Ltd. E-book: https://www.gutenberg.org/files/41360/41360-h/41360-h.htm

Gerbran, Allen, Chevalier, Jean. 2004. Dictionary of Symbols. Translated and adapted by Pavle Sekeruš, Kristina Koprivšek and Isidora Gordić. Novi Sad: Stylos, 2004.

Harvey, Graham. 2005. Animism: Respecting the Living World. Kent Town: Wakefield Press, 2005.

Jung, Carl G. (ed.). 1988. Man and His Symbols. New York: Anchor Press/Doubleday.

Jung, Carl Gustav. 1971. Psychological types. A revision by R. F. C. Hull of the translation by H. G. Baynes. Bolingen series XX. The collected works of C. G, Jung. Volume 6. Princeton University Press.

Jung, Karl Gustav. 1990. Dynamics of the Unconscious. Prepared by Dr. Vladeta Jerotić and Dr. Stevan Vlajković. Translated by Desa and Dr. Pavle Milekić. Novi Sad: Matica srpska, 1990.

Kostadinović 2014: D. Kostadinović, Elementi magičnog realizma u prozi Slobodana Džunića i Živka Činga, Beograd: Filološki fakultet. https://www.eteze.bg.ac.rs/application/shotheses?thesesld = 2221

Kulišić, Š., Petrović, Ž., Pantelić., 1970. Serbian mythological dictionary. Belgrade: Nolit.

Pejović, Danilo. 1989. "Animism". In: Philosophical Dictionary. Edited by Vladimir Filipović. Zagreb: Nakladni zavod Matice hrvatske, 1989, 27-28.

Radenković, Ljubinko.1996. Symbolism of the world in the folk magic of the South Slavs. Balkan Institute (SANU). Book 67. Niš: Prosveta.

Tolstoy, Svetlana M. and Radenković, Ljubinko. 2001. Slavic mythology (encyclopedic dictionary). Belgrade: ZEPTER BOOK WORLD.

Tylor, Edward Burnett. 1871. Primitive culture: Researches Into the Development of Mithology, Philosophy, Religion, Art and Custom. London: John Murray, Albemarle street.

\section{TRAGOVI ANIMIZMA U PROZI ŽIVKA ČINGA}

Polazeći od teoretskih postavki folkloristike, istorije religije, antropologije i psihoanalize, $u$ radu se izučavaju elementi animističkih verovanja u prozi makedonskog pisca Živka Činga. Građu za istraživanje čine pripovetke „Duhovi u kući“, „Zaljubljeni duh“, „,Ludi rođaci u borbi sa zlokobnim piletom " $i$ „Leptir sa zlatnim prahom". Cilj rada je da potvrdi da navedene pripovetke uspostavljaju sponu sa animizmom $i$ verom u postojanje duše u svim živim $i$ neživim stvarima $i$ pojavama u prirodi i verom da duša nastavlja da živi i nakon smrti.

Ključne reči: makedonska književnost, Živko Čingo, animizam, duh, duša, sen 